\title{
Children's Values, Social Support, Mother's Roles, and Psychosocial Stimulation in Boys and Girls
}

\author{
Dwi Hastuti ${ }^{1}$, Lia Shafira Arlianty ${ }^{2}$, Megawati Simanjuntak ${ }^{3 *}$ \\ ${ }^{1,3}$ Department of Family and Consumer Sciences, Faculty of Human Ecology IPB University, \\ Bogor 16680, Indonesia \\ ${ }^{2}$ Graduate from Child Development and Family Studies, Graduate School, IPB University, \\ Bogor 16680, Indonesia
}

*) Correspondence author: mega_juntak@apps.ipb.ac.id

\begin{abstract}
Psychosocial development is a developmental stage that every child will pass. This study aimed to analyze the influence of family and child characteristics, child value, social support, mother's involvement in psychosocial stimulation in boys and girls. The research design that was used in this study was a cross-sectional study. Site selection was chosen purposively, namely in the city of Medan. Research locations were in two villages, namely Kota Maksum, Medan Labuhan Subdistrict and Kota Besar Village, Medan Area District. The sample pulling technique uses simple random sampling with a sample of mothers who have children aged 2-3 years and come from a complete family of 150 people. Respondents interviewed with the questionnaire were mothers. Correlation test results showed a significant positive relationship between maternal age, children's values, dimensions of psychological value and dimensions of economic value, social support, dimensions of information support and dimensions of reward support, and mothers' role in care with psychosocial stimulation.
\end{abstract}

Keywords: children's value, mother roles, psychosocial stimulation, social support, toddler

\begin{abstract}
Abstrak
Perkembangan psikososial merupakan tahapan perkembangan yang akan dilalui oleh setiap anak. Penelitian ini bertujuan menganalisis hubungan karakteristik keluarga dan anak, nilai anak, dukungan sosial, peran ibu, dengan stimulasi psikososial pada anak laki-laki dan perempuan. Desain yang digunakan dalam penelitian ini adalah cross sectional study. Pemilihan tempat di pilih secara purposive, yaitu di Kota Medan. Lokasi penelitian di dua kelurahan, yaitu Kelurahan Kota Maksum Kecamatan Medan Labuhan dan Kelurahan Kota Besar Kecamatan Medan Area. Teknik penarik contoh menggunakan simple random sampling dengan contoh ibu yang mempunyai anak usia 2-3 tahun, dan berasal dari keluarga lengkap sebanyak 150 orang. Responden yang diwawancarai dengan kuesioner adalah ibu. Hasil uji korelasi menunjukkan terdapat hubungan signifikan positif antara usia ibu, nilai anak, dimensi nilai psikologis dan dimensi nilai ekonomi, dukungan sosial, dimensi dukungan informasi dan dimensi dukungan penghargaan serta peran ibu dalam pengasuhan dengan stimulasi psikososial.
\end{abstract}

Kata kunci: dukungan sosial, nilai anak, peran ibu, stimulasi psikososial, toddler 


\section{Introduction}

The toddler period is an essential part of the growth and development period and becomes the basis for determining the quality of the child. Growth and development at the age of 0-2 years is part of the golden age that needs attention. Child development begins with language skills, creativity, social, emotional, and intellectual awareness that caregivers need to pay attention to. According to Schunk (2012), children also begin to develop sensory, visual and auditory-motor skills, moral development, and personality basics. The family environment is the initial part of the parenting process and shapes children's optimal growth and development. Parents play a significant role in a family environment that can optimize children's growth and development. Children aged 6-24 months experience a critical period in their growth, which will cause failure to grow (Sukamti, Aticeh, \& Fauziah, 2014).

The number of children under five in Indonesia is around 10 percent of the total population of Indonesia, while children aged $0-4$ are 22.7 million $(9.54 \%)$ (Ministry of Health, 2014). Several regions in Indonesia have different coverage for early detection of the development and development of children under five. For example, the Health Profile of North Sumatra in 2012 states that conditions in Medan in 2012 , the coverage of early detection of their children was (35.6\%), while this was still far below the target set, namely $(90.0 \%)$. In the same year, the survey results showed 193,881 children under five in the city of Medan, carrying out Stimulation, Detection, and Early Development and Development (SDIDTK) services for preschool children, as many as 25,529 children (13.1\%), experienced malnutrition as many as 871 children (3.41\%), 22 children (0.09\%) experienced dubious developmental disorders based on the Child Development Pre Screening Questionnaire (KPSP). The results of the research by Polaha et al. (2011) described that the prevalence of psychosocial problems such as emotional disturbances was 10 percent and behaviour disorders in children were 19 percent. Another study said that the prevalence of psychosocial problems in children aged 2 to 6 years was 39.8 percent (Tarshis, Jutte, \& Huffman, 2006). This condition indicates that children still need the role of parents to optimize their psychosocial development.

Psychosocial development can be optimized through parenting practices and providing appropriate psychosocial stimulation. According to Caldwell and Bradley (1983), psychosocial stimulation is stimulation provided by parents and families to provide experiences, encourage learning and language, and encourage children's academic abilities. The stages of psychosocial development in Erik Erikson's theory are divided into eight stages of crisis development. Toddlers or children are the second stages of psychosocial development after infants in the age range of 18 months to 3 years, namely the autonomy vs doubt and shame stage (Santrock 2007; Sacco 2013). Important factors that influence the development of psychosocial autonomy in children so that this development can be adequately achieved include genetics and the environment (Wang \& Saudino, 2012). The thing that significantly affects the physical structure of the child's brain is stimulation in the first years of life so that children who do not receive psychosocial stimulation, such as rarely being invited to play or rarely spoken to, will experience various behavioural deviations (Permono, 2013). One of the forms of deviation in question is a missing self-image which results in inferiority, cowardice, and independence, or vice versa, children who are too aggressive and have no shame (Permono, 2013). According to Satoto (1990), there are differences in 
psychosocial stimulation in boys and girls, namely boys (aged less than 18 months) have better psychosocial stimulation than girls, and gender will influence parents in treating their children. For example, boys are given freedom compared to girls.

Providing stimulation is the main task of parents, especially mothers who play this vital role because mothers are the first and primary educators for children born until they are adults (Carolina, 2014). Home environment as an important indicator of early language development requires the presence of a mother. Mothers as the main party entrusted with the responsibility to organize parenting at home should possess an adequate ability to perform sufficient and proper stimulation (Iltus, 2007). The role of mothers is divided into three essential tasks, namely mothers as satisfying children's needs, mothers as role models or child imitation models and as stimulators for child development (Cahyani, 2009). Stimulation is helpful in the growth and development of organs that are not yet complete at birth, especially the stimuli provided by the mother. In addition, the stimulation provided by the mother will enrich the experience and have a significant influence on the child's cognitive, visual, verbal and mental development (Putri, 2016). Therefore, a safe and comfortable atmosphere, environment and support need to be created in the parenting process, especially stimulation (Carolina, 2014).

Mothers can perform their roles optimally if they get social support. The relationship between the family and the environment can encourage the formation of social support (Littlewood, Swanke, Stozier, \& Kondrat, 2012), while the decline in social support will negatively affect the emotional functioning and behaviour of children and negatively impact parents or caregivers both physically and mentally. The role of parents as caregivers requires social support from family and the environment. According to Muslima and Herawati (2018), more than half of the respondents felt the social support of large families, and the other half felt their neighbour's social support. The social support provided by the extended family is always present and will not change. Such support includes caring and attention.

MacArthur and John (1998) define social support as support (assistance) received by people from other people classified into three categories. These categories include emotional, instrumental and informational support. Family social support can be in the form of internal family social support, such as support from husband/wife or support from siblings, also known as external family social support (Friedman, 1998). Research shows that social support received by families can overcome problems experienced by families so that indirectly social support can support the childcare process to be more optimal and improve the quality of children (Herawati, 2011; Armstrong, Birnie-Lefcovitch, \& Ungar, 2005).

Optimization of psychosocial stimulation can also be linked to how parents perceive children's values. Family behaviour in allocating resources is strongly influenced by the values held by parents regarding the value of a child (Surachman, 2011). According to Rolston (1994), value is related to something that is desired or considered valuable. The value of the child is the main criterion in the actions of parents in raising children. Fazeli, Golmakani, Taghipour, and Shakeri (2016) divide children's values into three dimensions: children's emotional values, economic values, and social values. Some parents consider boys to be higher in value than girls so that the education of boys takes precedence over girls, as stated by (Mulatsih, Mulyaningrum, Pambudi 2002). Parents' perceptions of the value of children in the family will determine parenting practices that will impact the quality of the child (Hartoyo, 1998). 
Optimization of psychosocial stimulation can be related to children's values, the role of mothers in the parenting process and social support, so this research needs to be carried out. The novelty of this research is by examining boys and girls, especially in the city of Medan, which has a patriarchal culture.

Based on the background described, the objectives of this study are 1) to analyze differences in family characteristics, child characteristics, children's values, social support, maternal roles and psychosocial stimulation in boys and girls; 2) to analyze the relationship between family characteristics, children's characteristics, children's values, social support and the role of mothers in psychosocial stimulation.

\section{Methods}

\section{Participant}

This study used a cross-sectional study design, namely, data collection was carried out simultaneously on different objects. The research location was chosen purposively, namely Medan Labuhan District and Medan Area District, Medan City. The location selection is because it can represent both areas, namely urban and rural areas. In addition, the coverage of health services for a toddler in Medan in 2016 showed a high number of 151,694 toddlers compared to other cities in North Sumatra. It became the focus of attention for researchers (Health Profile of North Sumatra Province, 2016). This research is located in two sub-districts: Kota Maksum Village, Medan Labuhan District, Kota Besar Village, Medan Area District, and Medan City. The research stage consists of preparation, data collection, data processing, data analysis, and report writing from September 2016 to December 2017.

The population in this study were all families residing in Medan Labuhan and Medan Area subdistricts who have children aged 2 to 3 years. The sampling technique in this study was carried out using a simple random sampling technique, using a sampling frame of families with children aged 2-3 years at Posyandu from two selected sub-district. Respondents in this study were mothers. The criteria for research respondents were having children aged 2-3 years, coming from a complete family (intact), and willing to be used as sample. The number of samples of 150 pairs of mothers was determined using the Lemeshow formula (1997).

\section{Measurement}

Children's value is a parent's perception or expectation of a child in the future based on the child's abilities, both as an investment in the future (economic value), can increase social status (social value), and/or as an enhancer of happiness (psychological value). The children's score consists of 28 questions composed of three dimensions: psychological, social, and economical. This instrument is used to measure mothers' psychological, social, and economic values towards their children. This instrument modifies and refers to the Value of Children (VCHILD) developed by Shek (1993) with a Likert scale (1-3) including $1=$ strongly agree, 2 = agree, and $3=$ disagree, having a Cronbach's alpha value of 0.744 .

Social support is assistance received by mothers in emotional, instrumental, and information support from husbands, relatives / extended family. Social support has four dimensions, namely information support, instrument support, emotional support and assessment support. The instrument was modified and referenced from The 
Multidimensional Scale of Perceived Social Support instrument from Zimet et al. (1988). The questionnaire consists of 15 questions and uses a Guttman scale, namely 0 $=$ no and one $=$ yes, with a Cronbach's alpha value of 0.663 .

Maternal involvement is measured based on the level of frequency of the mother in carrying out certain activities with the child. The modified instrument and adopted from the Suciati (2013) questionnaire consisted of 13 questions and used an Ordinal scale including $0=$ never, one $=$ sometimes, $2=$ frequently, and $3=$ always, with a Cronbach's alpha value of 0.811 .

Psychosocial stimulation is a stimulation that is useful for optimizing the growth and development of children from the environment outside the child. Psychosocial stimulation is measured using the HOME Inventory (Bradley \& Caldwell, 1984), which consists of 45 questions that have six dimensions, namely sense and word responsiveness, acceptance of children's behaviour, organizing children's environments, providing toys for children, mother involvement with children, and opportunities. Variations in childcare, using the Guttman scale, namely $0=$ no and $1=$ yes, with a Cronbach's alpha value of 0.818 .

\section{Analysis}

Data processing was carried out through several activities, namely editing, coding, scoring, entering, cleaning, scoring and analysis. Categorizing children's scores, social support, maternal involvement, and psychosocial stimulation was carried out based on the score then transformed into an index. Three categories were used: low, medium, and high. The index score achieved is categorized based on Bloom's cut off point from Yimer, Abera, and Mulu (2013) to categorize the value of children, social support, mother's role in parenting, and psychosocial stimulation, namely; low (0.0060.00), medium (60.01-80.00) and high (80.01-100.00). Data processing and analysis were performed using the Microsoft Excel and Statistical Package for Social Science (SPSS) 16.0. The analysis used was descriptive analysis and inferential analysis, namely the t-test difference test and correlation.

\section{Findings}

\section{Children and Family Characteristics}

This study involved 150 children consisting of 65 boys and 85 girls. The mean age of boys in this study was 29.29 months, and the mean age of girls was 30.67 months. The age range of children in this study was 24 to 36 months. There is no significant age difference between boys and girls.

The results showed that most father's age (90.0\%) and mother's age (95.3\%) were in the early adulthood group with an average father's age of 32.28 years and an average mother's age of 28.71 years. The length of education of the father's sons and daughters is at the senior high school (SMA) education level, which is about 66.7 percent of the education of fathers with an average of 11.47 years and 62.0 per cent of the mother's education with an average of 11.42 years. More than three-quarters of the families $(76.9 \%)$ of boys and girls $(74.1 \%)$ are in the small family group, with an average number of male and female family members as many as three.

More than half of fathers of sons (55.4\%) and daughters (50.6\%) are selfemployed. The next job that the father of the son has is a private employee (26.2\%) and 
a driver/motorcycle taxi (6.2\%), while the father's next job is for the daughter of a private employee (17.26\%). Most of the mothers of boys $(86.2 \%)$ and girls $(89.4 \%)$ do not work or become housewives. The rest of the mothers work as private employees, entrepreneurs, labourers, civil servants, and traders. The income per capita owned by the families of boys and girls is in the range of Rp180.000.00-Rp2.000.000.00. There is no significant difference in the family income of boys and girls. The average family income for boys is in the range of IDR 250.000-IDR 2.000000. At the same time, the average family income of girls is in the range of IDR 180.000-IDR 1.500.000.00. The average income per capita per month in this study is IDR 753.557.00. According to BPS Kota Medan in 2014, the poverty line limit for Medan City is IDR 401.417.00 per capita per month. Therefore, the per capita income is above the poverty limit of Medan City, which is IDR 647.531.00, and it can be categorized as quite good in its socio-economic condition.

\section{Children's Value}

Table 1 shows that more than three-quarters $(76.0 \%)$ of the children's scores in this study were in the moderate category. In addition, 81.5 percent boys and The results showed no difference between boys and girls in the score of children (0.283).

Psychological Dimensions. The results showed that the psychological value dimension was in the high category with an average score of 72.7 percent. The psychological values were not significantly different between the parents of boys and girls. Almost all parents of boys and girls agree that the presence of children can strengthen the relationship between husband and wife. In addition, it can encourage more enthusiasm for work, and children are the gift of marriage, guarantee a sense of security in old age, provide joy, and happiness and children will be the main deterrent to divorce.

Table 1 Distribution of sample based on children's scores.

\begin{tabular}{|c|c|c|c|c|c|c|}
\hline \multirow{2}{*}{$\begin{array}{l}\text { Child's value } \\
\text { dimension }\end{array}$} & \multicolumn{3}{|c|}{ Total $(\%)$} & \multicolumn{2}{|c|}{ Average } & \multirow{2}{*}{ P-value } \\
\hline & Low & Medium & High & Boy & Girl & \\
\hline Psychological value & 1.3 & 26.0 & 72.7 & 86.92 & 84.22 & 0.128 \\
\hline Social value & $70 / 0$ & 28.7 & 1.3 & 57,00 & 55.00 & 0.357 \\
\hline Economic value & 38.7 & 46.7 & 14.6 & 64.50 & 65.54 & 0.659 \\
\hline Child's value total & 10.7 & 76.0 & 13.3 & 70.49 & 69.12 & 0.283 \\
\hline
\end{tabular}

Social Dimensions. The achievement of most of the parents $(70.0 \%)$ shows the social value is in a low category. Parents of boys and parents of girls strongly agree that if you have children, there must be a boy and a girl, boys are more valuable than girls, girls get sick more easily, so they need to be protected more than boys. There were no significant differences in the dimensions of social values between boys and girls.

Economic Dimensions. Table 1 shows that less than half $(46.7 \%)$ of parents in the economic value dimension are in the medium category with an average score of 65.09. The average index score for the boys 'parents' economic value was 64.51 and the girls' parents 65.55. Parents agree that the more children, the greater the cost to parents. This gives hope that children can provide economic assistance on a parental day, children, when they grow up and work, can help send their brothers and sisters to school, and girls will be the same as boys can work outside the home. There were no significant differences in economic scores between boys and girls. 


\section{Social Support}

Social support in total shows that eight tenths of families (82.7\%) are in the high category. This is because the four dimensions of social support, namely the dimensions of information, instrumental support, emotional support and appreciation support are categorized as high and there is no significant difference between social support for boys and girls.

Information Dimensions. Table 2 shows that parents getting information support is in the high category of 86.6 per cent. Information support was not significantly different between parents of boys and girls. The dimension of information support is in the high category because most parents of sons and daughters of the family can be relied upon in providing advice. In addition, the family provides marriage advice, and the family provides information about pregnancy. Furthermore, the family informs about breastfeeding and agrees that the family provides information about giving colostrum and providing information about complementary feeding.

Table 2 Distribution of sample based on social support

\begin{tabular}{|c|c|c|c|c|c|c|}
\hline \multirow{2}{*}{$\begin{array}{l}\text { Social support } \\
\text { dimensions }\end{array}$} & \multicolumn{3}{|c|}{ Total $(\%)$} & \multicolumn{2}{|c|}{ Average } & \multirow{2}{*}{ P-value } \\
\hline & Low & Medium & High & Boy & Girl & \\
\hline Information support & 6.7 & 6.7 & 86.6 & 89.74 & 91.37 & 0.505 \\
\hline Instrumental support & 8.0 & 22.0 & 70.0 & 87.18 & 87.06 & 0.973 \\
\hline Emotional support & 5.3 & 7.3 & 87.4 & 97.31 & 93.82 & 0.096 \\
\hline Appreciation support & 17.3 & 0.0 & 82.7 & 90.77 & 91.76 & 0.752 \\
\hline Social support total & 1.3 & 16.0 & 82.7 & 91.38 & 91.22 & 0.911 \\
\hline
\end{tabular}

Instrumental Dimensions. More than two thirds (70.0\%) of parents getting instrumental support is in the high category. There was no significant categorical difference $(\mathrm{P}-$ Value $=0.973)$ in instrumental support between boys and girls. The results showed that almost all parents of boys and girls received money or goods loans, received assistance in caring for the child, were assisted with housework when they were sick by their husbands and their closest relatives.

Emotional Dimensions. The research shows that the emotional dimension of the family is in the high category (87.4\%). Almost all parents of boys and girls often get solutions in solving problems, are willing to listen when there are problems, can be a place to tell stories or confide when there are problems and can be comforting when they are sad.

Appreciation Dimensions. The results showed that more than four-fifths $(82.7 \%)$ of parents who received appreciation support were in the high category. Almost all parents of boys and girls received respect for their small family and felt accepted by the extended family. There was no significant difference $(p=0.752)$ in support of appreciation between parents of boys and girls.

\section{Mother's Role}

The role of the mother is an activity carried out by the mother in providing care for the child. This study indicates that more than half $(55.4 \%)$ of boys 'parents and $(70.6 \%)$ girls' parents are in a low category. The average index on the role of mothers in childcare was 57.08 . Thus, more than half $(64.0 \%)$ of parenting roles were in a low category. The role of mother in parenting as a whole (composite) in this study found no significant difference $(\mathrm{p}=0.115)$ between parents of boys and girls. 


\section{Psychosocial Stimulation}

Based on the study results, the average psychosocial simulation score index as a whole was 57.3 on each scale, including low. This explains that psychosocial stimulation is not found to be a significant difference between boys.

Dimensions of Sense and Word Response. The parents' sense and word responsiveness results are in the high category $(43.3 \%)$. The majority of parents were seen talking to their children, mothers responded to children's babbling, mothers answered questions and actively spoke, mothers spoke freely without being covered up, and mothers seemed to show affection for their children through words.

Acceptance Dimensions of Children's Behaviour. Table 3 shows that less than half $(44.0 \%)$ of the acceptance of children's behaviour is in the moderate category. There was no significant category difference $(\mathrm{p}=0.821)$ in the dimensions of acceptance of children's behaviour between boys and girls. Less than half of mothers shouted at their children, have shown disappointment to children, have punished their children in the past week, have scolded their children, and mothers have forbidden their children to play at will.

Environmental Organizing Dimensions. More than half (56.0\%) of parents in organizing children's environments are in a low category. There was no significant difference ( $p=0.698)$ in the organization of the children's environment between boys and girls. More than half of boys and girls in one week invited the children to go to market shop, invited to leave the house, and child taken to the doctor for treatment last three months.

Provision of Toys for Children Dimensions. Research shows that more than half $(54.0 \%)$ of parents in providing toys for children are in a low category. There was no significant difference $(\mathrm{p}=0.645)$ in the organization of the children's environment between boys and girls. Parents of boys and girls do not provide simple hand-eye coordination toys such as boxes and lids, are not provided with more complex hand-eye coordination toys. Three parts of the toy are put together, and the mother does not provide learning tools for drawing or writing or playing music.

Table 3 Distribution of sample based on psychosocial stimulation

\begin{tabular}{|c|c|c|c|c|c|c|}
\hline \multirow{2}{*}{$\begin{array}{l}\text { Dimension of psychosocial } \\
\text { stimulation }\end{array}$} & \multicolumn{3}{|c|}{ Total $(\%)$} & \multicolumn{2}{|c|}{ Average } & \multirow{2}{*}{ P-value } \\
\hline & Low & Medium & High & Boy & Girl & \\
\hline Sense and word response & 35.0 & 21.3 & 43.3 & 70.49 & 69.52 & 0.767 \\
\hline Acceptance of children's behaviour & 37.3 & 44.0 & 18.7 & 57.69 & 58.68 & 0.821 \\
\hline Environmental organizing & 56.0 & 24.7 & 19.3 & 55.89 & 54.12 & 0.698 \\
\hline Provision of toys for children & 54.0 & 28.7 & 17.3 & 56.75 & 58.69 & 0.645 \\
\hline Mother involvement in children & 65.3 & 14.7 & 20.0 & 50.51 & 54.12 & 0.361 \\
\hline Opportunity variation of care & 72.0 & 21.3 & 6.7 & 46.15 & 49.88 & 0.420 \\
\hline Psychosocial stimulation total & 57.3 & 32.7 & 10.0 & 58.15 & 59.13 & 0.694 \\
\hline
\end{tabular}

Dimensions of Mother Involvement in Children. The mother involved almost two-thirds of the children in the low category (65.3\%). There was no significant difference $(p=0.361)$ in the involvement of mothers with children between parents of boys and girls. More than half of the parents of boys and girls do not supervise their children playing, do not talk to children, ignore and stimulate children's development. 
Opportunity Variation of Care Dimensions. The care given by the mother has shown variations in the care of the category, almost three-quarters $(72.0 \%)$ of the parents provide the opportunity for the variation of childcare to be in a low category. There was no significant difference $(\mathrm{p}=0.420)$ in the dimension of opportunity for variation in childcare between boys and girls. The parents of boys stated that the husband did not participate in caring for the child every day, in contrast to the parents of the girl who stated that the husband participated in caring for the child every day, in one week they never told their children, the child was never visited or visited the family in one month. The daughter's parents do not have books for their own children.

\section{Relationship between Family Characteristics, Child Characteristics, Child Values, Social Support, Mother Roles and Psychosocial Stimulation}

Table 4 shows that there is a positive relationship between maternal education ( $\mathrm{r}$ $=0.172 ; \mathrm{p}<0.05)$, the dimension of psychological value $(\mathrm{r}=0.189 ; \mathrm{p}<0.05)$, the dimension of information support $(\mathrm{r}=0.205 ; \mathrm{p}<0.05)$, and the role of the mother in parenting $(r=0.163 ; p<0.05)$ with psychosocial stimulation. This means that the higher the mother's education, psychological value, information support and mother's role in parenting, the better the psychosocial stimulation parents give to their children. There is a negative relationship between family size $(r=-0.169 ; \mathrm{p}<0.05)$ and psychosocial stimulation. This shows that the more family members there are, the less stimulation the parents give to their children.

There is a positive relationship between maternal age $(\mathrm{r}=0.181 ; \mathrm{p}<0.05)$, children's scores $(r=0.161 ; p<0.05)$, psychological value dimensions $(r=0.177 ; p$ $<0.05)$, social support $(\mathrm{r}=0.219 ; \mathrm{p}<0.01)$, the dimensions of information support $(\mathrm{r}=$ $0.169 ; \mathrm{p}<0.05)$, the dimensions of appreciation support $(\mathrm{r}=0.187 ; \mathrm{p}<0.05)$ and the mother's role in parenting $(r=0.164 ; \mathrm{p}<0.05)$ with the dimensions of sense and word responsiveness (Table 4). This means that the more mature the mother's age, the higher the child's value, psychological value, social support, information support, assessment support and the role of the mother in parenting, the better the response of feelings and words given to the mother and obtained by the child.

Positive relationships were also seen in social support $(r=0.169 ; \mathrm{p}<0.05)$, the dimensions of information support $(r=0.161$; $p<0.05)$, and reward support $(r=0.179$; $\mathrm{p}<0.05$ ) with the dimensions of acceptance of behavior. children (Table 4). This shows that the higher the social support, information support and reward support parents get, the better acceptance of children's behaviour will be. Instrumental support ( $r=0.187$; $p$ $<0.05)$ has a positive relationship with the dimensions of organizing the child's environment. The higher the instrumental support, the better environmental organizing is given to the child. 
Table 4 Relationship between family characteristics, child characteristics, children's values, social support, mother's role in caring, and psychosocial stimulation

\begin{tabular}{|c|c|c|c|c|c|c|c|}
\hline Variable & SWR & ACB & CEO & PTC & MIC & OVC & PST \\
\hline \multicolumn{8}{|l|}{ Family Characteristics } \\
\hline Father's age (year) & 0.053 & 0.141 & -0.100 & -0.013 & 0.097 & 0.094 & -0.051 \\
\hline Mother's age (tahun) & $0.181 *$ & 0.093 & -0.016 & 0.149 & $0.187 *$ & $0.170 *$ & 0.101 \\
\hline $\begin{array}{l}\text { Father's education } \\
\text { (year) }\end{array}$ & -0.027 & -0.072 & 0.065 & 0.021 & -0.054 & -0.044 & -0.009 \\
\hline $\begin{array}{l}\text { Mother's education } \\
\text { (year) }\end{array}$ & 0.136 & -0.033 & 0.157 & 0.047 & 0.099 & 0.083 & $0.172 *$ \\
\hline $\begin{array}{l}\text { Mother's working } \\
\text { status }\end{array}$ & 0.135 & -0.052 & 0.158 & 0.120 & $0.164 *$ & -0.040 & 0.126 \\
\hline Family size (member) & 0.002 & -0.076 & 0.048 & -0.009 & 0.034 & $0.173^{*}$ & $-0.169 *$ \\
\hline $\begin{array}{l}\text { Income per capita } \\
\text { (rupiah) }\end{array}$ & 0.003 & -0.017 & 0.081 & -0.018 & -0.008 & -0.095 & 0.053 \\
\hline \multicolumn{8}{|l|}{ Child characteristics } \\
\hline Usia anak (month) & 0.067 & 0.027 & 0.086 & 0.035 & 0.057 & -0.027 & 0.048 \\
\hline Child's Value (index) & $0.161 *$ & 0.154 & -0.026 & 0.133 & 0.121 & 0.159 & 0.064 \\
\hline Psychological value & $0.177 *$ & 0.095 & 0.022 & 0.120 & $0.180 *$ & 0.051 & $0.189 *$ \\
\hline Social value & 0.011 & 0.076 & -0.084 & -0.018 & 0.024 & 0.121 & -0.082 \\
\hline Economic value & $0.162 *$ & 0.156 & 0.022 & $0.200 *$ & 0.045 & $0.161 *$ & 0.036 \\
\hline Social Support (index) & $0.219 * *$ & $0.169^{*}$ & 0.090 & $0.176^{*}$ & $0.192 *$ & -0.007 & 0.151 \\
\hline Information support & $0.169 *$ & $0.161 *$ & 0.002 & 0.103 & 0.133 & 0.021 & $0.205^{*}$ \\
\hline Instrumental support & 0.088 & 0.039 & $0.187 *$ & 0.049 & 0.058 & -0.065 & 0.000 \\
\hline Emotional support & 0.040 & -0.009 & -0.003 & 0.107 & 0.070 & -0.015 & -0.013 \\
\hline Appreciation support & $0.187 *$ & $0.179 *$ & 0.001 & 0.155 & $0.180 *$ & 0.062 & 0.085 \\
\hline $\begin{array}{l}\text { Mother's role in } \\
\text { parenting }\end{array}$ & $0.164 *$ & 0.044 & 0.007 & 0.131 & 0.150 & 0.150 & $0.163 *$ \\
\hline $\begin{array}{ll}\text { Notes: } & * * \text { ) signific } \\
& \text { (Acceptance } \\
& \text { toys for chil } \\
& \text { (Psychosoci }\end{array}$ & $\mathrm{p}<0$. & SIgIII & at $P$ & ; SWR & ise and & ord Res & $\begin{array}{l}\text { se); ACB } \\
\text { ovision of } \\
\text { are); PST }\end{array}$ \\
\hline
\end{tabular}

Table 4 shows a positive relationship between the dimensions of economic value $(\mathrm{r}=0.200 ; \mathrm{p}<0.05)$ and social support $(\mathrm{r}=0.176 ; \mathrm{p}<0.05)$ with the dimensions of providing toys for children. That means that the better the economic value and social support, the better the provision of toys for children by parents. There is a positive relationship between maternal age $(\mathrm{r}=0.187 ; \mathrm{p}<0.05)$, working mother status $(\mathrm{r}=$ $0.164 ; \mathrm{p}<0.05)$, psychological value dimensions $(\mathrm{r}=0.180 ; \mathrm{p}<0.05)$, social support $(\mathrm{r}=$ $0.192) ; p<0.05)$, and the dimensions of appreciation support $(r=0.180 ; p<0.01)$ with the dimensions of maternal involvement in children. It means that the more mature the mother is, the mother who does not work, the higher the psychological value, social support and appreciation support, the better the mother's involvement with the child. Positive relationships were also seen at the mother's age $(r=0.170 ; \mathrm{p}<0.05)$, family size $(r=0.173 ; p<0.05)$, and the dimensions of economic value $(r=0.161 ; p<0.05)$ with the dimension of opportunity for variation in care (Table 4). The result shows that the more mature the mother is, the more family members are, and the higher the economic value, the better and more varied the opportunities for variations in child care are. 


\section{Discussion}

This research uses structural-functional theory. The development and growth of children under five must be considered, one of which is by optimizing psychosocial stimulation. The results showed that the provision of psychosocial stimulation to boys and girls was still insufficient and not optimal. This condition is due to the mother's lack of knowledge and education regarding child development and the wife's dissatisfaction in the division of responsibility for raising children (Putri \& Herawati, 2017). In line with the research of Latifah, Alfiasari and Hernawati (2009) that the quality of care in Ciampea District is in the moderate category because the mother's knowledge in carrying out the care process is still low so that the mother is less varied in caring and does not optimize the facilities and infrastructure needed in the process stimulation which has an impact on delays in child development. In addition, it was also found that some mothers can provide optimal care in terms of taste and word responsiveness.

While overall psychosocial stimulation is in a low category, but in the responsiveness, taste and word dimensions, it is quite good. Research by Latifah, Alfiasari and Hernawati (2009) states that risk factors that affect parenting and development are low parental education, low family income, low knowledge of parenting, and lack of facilities and infrastructure. Education is a factor that influences women in caring for, caring for and looking after children (Signh, Rai, \& Signh, 2012). Dewanggi (2014) also states that the mother's age influences the quality of the childcare environment at marriage. Mothers who are married at a more mature age will have better education and parenting knowledge to stimulate children's development. Similar to Wahyuningsih and Krisnatuti's (2017) research, the age of mothers who tend to be younger has good emotional intelligence and will affect the formation of good children's learning motivation. This creates a warm childcare environment. In addition, a relationship with a husband that is not harmonious due to a young age will cause the mother to be less than optimal in providing care (Tras \& Herawati, 2017). Based on the results of different tests, there is no significant difference between parents of boys and girls on the psychosocial stimulation variable.

Psychosocial stimulation will be related to the role of mothers in providing, facilitating, and maximizing their resources. The role of mothers in the study shows that they are still in a low category. When perceived parenting skills diminished over time due to physical limitations or psychological distress, mothers' sense of failure in fulfilling their parenting role increased, perpetuating low parenting confidence and efficacy, anxiety, shame and guilt (Fisher, C \& O'Connor, 2012; Bekteshi \& Kayser, 2013; Croson \& Keim-Malpass, 2016). In addition, mother also has not optimized the motherly function, love and care for her child according to research (Ceka \& Murati, 2016), namely the function of motherhood is related to child development, physical development, intellectual development and emotional development of children, the type of love and affection.

In optimizing the mother's psychosocial stimulation, social support is needed. The social support felt by mothers in this study, for example, felt helped in parenting. The family is a system the dynamics that occur between husband and wife will affect the social support of the husband to his wife in parenting. Mothers receive more support from family, friends and partners, while husbands tend to get the most social support only from partners. Mothers receive social support from neighbours, including emotional, instrumental and informational support. In line with Herawati's research, 
Kumalasari, Musthofa and Tyas (2018) state that wives receive high social support from extended family and neighbours. The wives feel that they get support from the extended family in listening to the problems they face, showing feelings of love and care, close relationships, appreciating feelings and understanding their feelings. This study also suggests that wives receive social support from neighbours, including emotional, instrumental and information support that is well achieved. The instrumental support and information received by the mother are sufficient, but there are still some aspects of this that are less than optimal in terms of providing financial assistance and child care. Suppose the mother has optimal social support from the surrounding environment. In that case, the mother can establish a good relationship with her husband, extended family, and neighbours so that all systems will help stimulate the child.

Parents' views regarding children's values can also lead to different stimulation. The care that the mother carries out is based on the knowledge that the mother has, however, the knowledge and skills possessed by the mother are often inadequate. One of the influencing factors is the mother's education level (Khomsan, 2000). If mothers have high knowledge, mothers will be more active in seeking information to increase their knowledge and skills in childcare. Parents 'parenting methods are closely related to parents' perceptions of children's worth. The value of a child for parents in everyday life can be seen from the condition that the child is a place to pour out love and a source of family happiness (psychological value) so that parents will provide optimal psychosocial stimulation through high levels of education, and have a positive perception of their child (Hastuti, Alfiasari \& Chandriyani, 2010). There is a significant and positive relationship between children's scores and children's psychosocial stimulation. This means that the higher the child's score, the higher the psychosocial stimulation (Hastuti, Alfiasari \& Chandriyani, 2010).

The results of the study found that there was no difference between the scores for boys and girls. This is in line with Aninda's (2013) research on early adult and middle adult mothers in Batak, who stated that even though psychologically, socially and economically they hope to have a son, they still have positive feelings when giving birth to a girl. Mothers can accept the presence of their daughters because they think boys and girls are the same and have become gifts from God. Tirsani (2013) found a similarity in values between boys and girls in Bali, which states that there is no relationship between the perception of the value of the child and the sex of the child desired by premarital women of childbearing age so that the sex of the child is not important to differentiate. There is no relationship between children's scores and the sex of the child (Putri, 2015).

The results of the different test showed that there were no significant differences between boys and girls on all dimensions of social support. The correlation test analysis shows a positive relationship between maternal education, dimensions of psychological value, dimensions of information support, and the role of mothers in parenting with psychological stimulation. This means that the higher the mother's education, psychological value, information support and mother's role in parenting, the better the psychosocial stimulation parents give to their children. There is a negative relationship between family size and psychosocial stimulation, and this shows that the more family members there are, the more stimulation parents give to their children. This is in accordance with the results of research by Purwati and Laili (2016) that maternal education affects children's psychosocial development because more knowledge and information is obtained so that it can easily stimulate children's development well, as 
well as research results (Reich, 2005: Ribas Jr. \& Bornstein, 2005: Hastuti, Fiernanti, \& Guhardja, 2011: Elmanora, Muflikhati, \& Alfiasari, 2012), states that maternal education is positively related to psychosocial stimulation.

There is a positive relationship between maternal age, children's scores, dimensions of psychological values, social support, dimensions of information support, dimensions of appreciation support, and mothers' role in parenting with the dimensions of sense and word responsiveness. This means that the more mature the mother's age, the higher the child's value, psychological value, social support, information support, assessment support and the role of the mother in parenting, the better the provision of sense and word stimulation given to the mother and obtained by the child. In line with Hastuti (2009), the maturity of a mother's age can form emotional stability and the ability to control self-emotions. In addition, the maturity of thinking can shape a person's emotional, social maturity to shape behaviour when interacting with children. The greater the size of the family, the lower the psychosocial stimulation given to the child. This is in accordance with the results of previous research, which states that the more dependents the family has, the more it makes the family not focus on children in providing facilities, stimulation, and affection for children (Rizkillah, Sunarti, \& Herawati, 2015)

Positive relationships can also be seen in social support, the dimensions of information support, and appreciation support with the dimensions of acceptance of children's behaviour. This shows that the higher the social support, information support and reward support parents get, the better acceptance of children's behaviour will be. Instrumental support is positively related to the dimensions of organizing the child's environment, meaning that the higher the instrumental support for environmental organizing is given to the child, the better. Komalasari (2006) states that social support can make parents realize a nearby environment, namely their extended family, who is ready to help when their parents face pressure. Social support provided by extended families is in the form of informational, instrumental, emotional and assessment support (Adicondro \& Purnamasari, 2011). The social support provided by this extended family can make parents feel cared for, comfortable, safe, cared for and loved by their extended family so that parents are better able to optimize care for their children, especially with regard to sense and word stimulation (Ermayanti \& Abdullah, 2007).

There is a positive relationship between the dimensions of economic value and social support and the dimensions of providing toys for children. This means that the better the economic value and social support, the better the provision of toys for children by parents. There is a positive relationship between maternal age, working mother status, dimensions of psychological value, social support, and dimensions of reward support with dimensions of mother involvement in children. This means that the more mature the mother is, the mother who does not work, the higher the psychological value, social support and appreciation support, the better the mother's involvement with the child. Positive relationships can also be seen in the mother's age, the size of the family, and the dimension of economic value with the dimension of variation in care opportunities. This shows that the more mature the mother is, the more family members are, and the higher the economic value, the better and more varied the opportunities for variations in child care are.

Some of the limitations of this study are that it does not measure the role of the father in parenting but only focuses on the mother. The research assesses only one point in time, so it is less likely to reflect true parenting. 


\section{Conclusion and Recommendation}

\section{Conclusion}

The value of the child is in the medium category. The highest score for children comes from the dimension of psychological values, and the lowest is from the dimension of social values. There is no difference between the scores for boys and girls for parents, especially in Medan City. Social support is in the high category. The most social support given by husbands and close families to mothers was emotional support, and the lowest received by mothers was instrumental support. There is no difference in social support for boys and parents of girls, the support provided by husbands and close relatives are the same for the mother of boys and girls. The role of mothers in parenting is in a low category.

There is no difference in the role of mothers in the care of boys and girls. Psychosocial stimulation is included in the low category. The mother gives the highest stimulation to the child, namely the response to taste and words and the lowest stimulation, namely the opportunity for variations in child care, which shows that parents cannot provide and implement variations of care for children that can stimulate children's development. The results showed that there was a positive relationship between maternal education, dimensions of psychological values, dimensions of information support, and the role of mothers in parenting with psychosocial stimulation, and there was a negative relationship between family size and psychosocial stimulation.

\section{Recommendation}

Based on the results of the research, it shows that the child's value is not optimal, the role of mothers in parenting and psychosocial stimulation in Medan City, so that the advice that can be given is that the hope of children in the future can be increased based on the children's abilities, as future investments (economic, social status and happiness) so that the stimulation process can run well. The role of parents in caring is further enhanced for children and increases knowledge of psychosocial stimulation through parenting education for mothers on how to stimulate children, which can be done in coordination with the Family Welfare Empowerment mobilizing team, the Early Childhood Education groups, government (BKKBN and BKB), universities or activists and institutions- Child care institutions and information through outreach on how to care for and care for children according to their developmental stages, have an awareness of the importance of facilities and infrastructure for stimulating children to improve children's development and quality. And in this study, the government recommends that the family planning program to have two children is better implemented so that stimulation and care can be more optimal because the results show that the bigger the family members, the stimulation given to children decreases. 


\section{References}

Adicondro, N., \& Purnamasari, A. (2012). Efikasi diri, dukungan sosial keluarga dan self regulated learning pada siswa kelas VIII. HUMANITAS: Indonesian Psychological Journal, 8(1), 17-27.

Aninda, R. N. (2013). Nilai anak perempuan pada keluarga batak ditinjau dari ibu dewasa awal dan dewasa madya. Jurnal Ilmiah Mahasiswa Universitas Surabaya, 2(1), 1-13. Retrieved from: http://journal.ubaya.ac.id/index.php/jimus/article/view/394/260

Armstrong, M. I., Birnie-Lefcovitch, S., \& Ungar, M. T. (2005). Pathways between social support, family well being, quality of parenting, and child resilience: What we know. Journal of child and family studies, 14(2), 269-281. doi: $10.1007 / \mathrm{s} 10826-005-5054-4$

Bekteshi, V., \& Kayser, K. (2013). When a mother has cancer: pathways to relational growth for mothers and daughters coping with cancer. Psycho-Oncology, 22(10), 2379-2385. doi: https://doi.org/10.1002/pon.3299

Bradley, R., \& Caldwell, B.M. (1984). Home observation for measurement of the environment (HOME)-revised edition. Amerika Serikat, US: University of Arkansas

Cahyani, P. B. (2009). Hubungan pengetahuan ibu dengan perkembangan motorik kasar anak usia 3-5 tahun di Boyolali [tesis]: Universitas Muhammadiyah Surakarta, Surakarta.

Caldwell, B., \& Bradley, R. (1983). Home Observation for Measurement of The Environment (HOME) Inventory. Winsor Drive, Eau Claire. Lorraine Coulson HOME INVENTORY LLC.

Carolina, R. (2014). Optimalisasi tumbuh kembang anak dalam membangun pendidikan merupakan tanggung jawab orang tua. Jurnal Keluarga Sehat Sejahtera, 12(24).

Ceka, A., \& Murati, R. (2016). The Role of Parents in the Education of Children. Journal of Education and Practice, 7(5), 61-64.

Croson, E., \& Keim-Malpass, J. (2016). Grief and gracefulness regarding cancer experiences among young women. In Oncology nursing forum, 43(6):747-53. doi: 10.1188/16.ONF.747-753

Ermayanti, S., \& Abdullah, S. M. (2007). Hubungan antara persepsi terhadap dukungan sosial dengan penyesuaian diri pada masa pensiun. Jurnal InSight. 5(148), 170.

Fazeli, E., Golmakani, N., Taghipour, A., \& Shakeri, M. T. (2016). Intergenerational Comparison of Value of Children among Urban Women Population in Mashhad, Iran, 2014. Journal of Midwifery and Reproductive Health, 4(4), 732-740. doi: 10.22038/JMRH.2016.7306

Fisher, C., \& O'Connor, M. (2012). "Motherhood" in the context of living with breast cancer. Cancer Nursing, 35(2), 157-163. doi: 10.1097/NCC.0b013e31821cadde

Friedman, M. M. (1998). Family nursing, theory and practice (3rd ed). Amerika serikat, US: Applenton \& Lange.

Hartoyo. (1998). Investing in children: study of rural families in Indonesia. [dissertation]. Virginia Tech University. Blacksburg, Amerika Serikat

Hastuti, D. (2009). Stimulasi psikososial pada anak kelompok bermain dan pengaruhnya pada perkembangan motoric, kognitif, sosial emosi, dan oral/karakter anak. Jurnal Ilmu Keluarga \& Konsumen, 2(1), 41-56. doi: 10.24156/jikk.2009.2.1.41. 
Hastuti, D., Fiernanti, D. Y. I., \& Guhardja, S. (2011). Kualitas lingkungan pengasuhan dan perkembangan sosial emosi anak usia balita di daerah rawan pangan. Jurnal Ilmu Keluarga dan Konsumen, 4(1), 57-65. doi: http://dx.doi.org/10.24156/jikk.2011.4.1.57.

Health Profile of North Sumatra Province. (2016). Profil Kesehatan Provinsi Sumatera Utara Tahun 2016. Medan: Dinas Kesehatan Provinsi Sumatera Utara.

Herawati, L. H. (2011). Pengaruh komposisi jenis kelamin anak terhadap peningkatan paritas di Provinsi Sumatra Utara dan Sumatra Barat (Analisis SDKI 2007). [tesis]. Universitas Indonesia, Indonesia

Iltus, S. (2007). Significance of home environments as proxy indicators for early childhood care and education. Paper commissioned for the EFA Global Monitoring Report.

[Kemenkes RI] Kementerian Kesehatan RI. (2014). Laporan Hasil Riset Kesehatan Dasar (RISKESDAS). Jakarta: Badan Penelitian dan Pengembangan Kesehatan, Kemenkes RI.

Lemeshow, S. (1997). Besar Sampel dalam Penelitian Kesehatan. Yogyakarta: Gajahmada University Press.

Littlewood, K., Swanke, J., Stozier, A., \& Kondrat, D. (2012). Measuring social support among kinship caregivers: Validity and reliability of the family support scale. Child Welfare, 91(6), 59-78.

MacArthur, T., \& John, D. (1998). Social Support \& Social Conflict. www.macses.ucsf.edu/research/psychosocial/notebook/socsupp. [Mar 7, 2017]. Development in Third World. New York (US): Rovlledge in Cooperation with Unecso, London.

Mulatsih, S., Mulyaningrum, \& Pambudi, R. (2002). Perilaku investasi pendidikan bagi anak perempuan dibandingkan anak laki-laki: Suatu tinjauan ekonomis. Bogor: Fakultas Peternakan, Institut Pertanian Bogor.

Muslima, F., \& Herawati, T. (2018). The role of social support and marital adjustment to marital quality of married student. Journal of Family Sciences, 3(2), 30-41. doi: https://doi.org/10.29244/jfs.3.2.30-41

Permono, H. (2013). Peran orangtua dalam optimalisasi tumbuh kembang anak untuk membangun karakter anak usia dini. Prosiding Seminar Nasional Parenting. 3437.

Retrieved

from: https://publikasiilmiah.ums.ac.id/xmlui/bitstream/handle/11617/3994/02.pdf?sequ ence $=1 \&$ is Allowed $=\mathrm{y}$

Polaha, J., Dalton W. T, \& Allen, S. (2011). The prevalence of emotional and behavior problems in pediatric primary care serving rural children. Journal Of Pediatric Psychology, 36(6), 652-660.

Putri, C. Y. Y. P. (2016). Hubungan persepsi nilai anak dengan jumlah dan jenis kelamin anak yang diinginkan pada wanita usia subur pranikah di perdesaan. Biometrika dan Kependudukan,3(1), 143-149. Diambil dalam http://journal.unair.ac.id/filerPDF/biometrik7ae7b3753afull.pdf

Rolston, H. (1994). Value in nature and the nature of value. Royal Institute of Philosophy Supplement, 36, 13-30. doi:10.1017/s1358246100006421

Sacco, R. G. (2013). Re-envisaging the eight developmental stages of erik erikson: The fibonacci life-chart method (FLCM). Journal of Educational and Developmental Psychology, 3(1), 140-146. 
Santrock, J. W. (2007). Perkembangan Anak. Edisi kesebelas jilid 2, Rahmawati M, A Kuswati, penerjemah; Hardani W, editor. Jakarta (ID): Penerbit Erlangga, Terjemahan dari: Child.

Satoto. (1990). Pertumbuhan dan perkembangan anak, pengamatan anak umur 0-18 bulan di Kecamatan Mlonggo Kabupaten Jepara Jawa Tengah. [disertasi]. Universitas Diponegoro Semarang, 7(10), 139-140

Schunk, D. H. (2012). Learning Theories An Educational Perspective Teori-Teori Pembelajaran: Perspektif Pendidikan (Edisi keenam). Yogyakarta: Pustaka Pelajar.

Siedlecki, K. L., Salthouse, T. A., Oishi, S., Jeswani, S. (2013). The relationship between social support and subjective well-being across age. Social Indicators Research. doi: 10. 1007/s11205-013-0361-4.

Suciati, M. (2013). Analisis persepsi nilai anak dan perilaku investasi waktu orang tua pada anak (Kasus Di Desa Situ Udik, Kecamatan Cibungbulang, Kabupaten Bogor [skripsi]. Bogor: Institut Pertanian Bogor.

Sukamti, S., Aticeh, A., \& Fauziah, F. (2014). Stimulasi dini pada pola asuh berdampak positif terhadap perkembangan anah bawah dua tahun. Jurnal Ilmu dan Teknologi Kesehatan (JITek), 2(1), 27-35.

Sunarti, E., Tati., Atat, S. N., Noorhaisma., \& Lembayung, D. P. (2005). Pengaruh tekanan ekonomi keluarga, dukungan sosial, kualitas perkawinan, pengasuhan, dan kecerdasan emosi anak terhadap prestasi belajar anak. Jurnal Media Gizi Dan Keluarga, 29(1), 34-40.

Surachman, A. (2011). Born to be destitute: capital transfer and intergenerational transfer of poverty. Undergraduate Research Journal for the Human Sciences. 11. Retrieved from: http://www.kon.org/urc/v11/surachman.html.

Tarshis, T. P., Jutte, D. P., \& Huffman, L. C. (2006). Provider recognition of psychosocial problems in low-income latino children. Journal Of Health Care For The Poor And Underserved, 17(2), 342-357. doi: 10.1353/hpu.2006.0070

Tirsani, N. M. A. D. (2013). Value children pada keluarga bali ditinjau dari jenis kelamin anak. [tesis]. Universitas Surabaya, Surabaya, Indonesia

Wahyuningsih, I. S., \& Krisnatuti, D. (2017). Mother's parenting style, sibling relationship, and learning motivation of youngest child adolescent. Journal of Family Sciences, 2(1), 15-27. doi: https://doi.org/10.29244/jfs.2.1.15-27

Wang, M., \& Saudino, K. J. (2012). Genetic and environmental contributions to stability and change of sleep problems in toddlerhood. Journal Of Pediatric Psychology, 37(6), 697-706.

Yimer, M., Abera, B., \& Mulu, W. (2013). Knowledge, attitude and practices of high risk population on Louse-Borne Relapsing Fever. Science Journal of Public Health, 101(16), 4-8. doi: 10.11648.j.sjph.20140201.13 